precious systematic part of the Entomological department. When will our National museum fully warrant its name by becoming the one legitimate and most satisfactory repository of all such collections in whatever branch of science?

In closing this brief notice of one whose personal relations and whose appreciative and instructive correspondence with the writer during the past fifteen years will ever remain a green and pleasant memory, we would emphasize the fact that his writings throughout breathe a calm and judicial spirit, void of personality. The only instance that occurs to us where he gave expression to ruffled feeling is in the "Synopsis of the coleopterous insects of the group cleridae which inhabit the United States" (Annals lyceum nat. hist. N.Y., April I 849, v. 5, p 9-35). In the prelude to this paper he indulges in some severe reflections on the exclusive attitude of the Latin or South European countries toward the scientists of other countries. more particularly as exemplified by Spinola's work - reflections not altogether unwarranted even at the present time.

\title{
GILLS OF INSECT-LARVAE.
}

\section{By GeORge MACloskie, PRINCEton, N. J.}

The gills of aquatic larvae of insects consist of elastic sacs arising as outgrowths of the epidermis and enclosing a system of fine branches from the airtubes or tracheae, being thus pneumatic branchiae. They vary greatly in the number of the sacs, in the number and complexity of the enclosed air-tubes, and in their position. In the elmidae (of coleoptera) they are simple and are distributed ventrally on the abdomen ; in Ephemera (of neuroptera) they are also simple, and extend from the sides of the abdomen; sometimes they are caudal appendages, and in the libellulidae, or dragon-flies, they become complex, having in some cases many sac-like lamellae, and many hundreds of branches in each, the whole structure planted within the rectum, from the walls of which the lamellar sacs open like so many pockets.
These structures have been described by Réaumur, Léon Dufour, Audouin, Oustalet, ${ }^{1}$ and many others. Our present purpose is to rectify an error in their anatomy, as usually represented, which has important bearings on other questions.

It is usual to describe the laminae of the pneumatic gills as containing systems of fine tracheal loops, somewhat after the pattern of a plurality of carbonwicks in an Edison lamp. Oustalet says, for example, in the Annales des sciences naturelles (1869, s. 5, v. I I), that the branchial laminae "include a veritable chevelu of tracheae folded on themselves so as never to reach the extremity of the fingers of the glove;" and that they serve as a loose sheath

1 Ann. des sci. nat., Zool., 1852, s. 3 , v. 17 ; 1862, s. 4 , v. $17 ; 1869$, s. 5 , v. $11 ; 1872$, s. 5 , v. 16 . 
for a tracheal arbuscle (shrubbery) whose last ramifications are not only recurved but anastomosed so as to complete the circuit (a plein canal), thus forming veritable arches (anses). His figure agrees with his descriptive representation, showing the very numerous ultimate branches of the tracheae as completely arched, and his idea evidently was that there is a capillary circulation of air in the tracheal tubules like the capillary circulation of blood in the gills of fishes.

Chun $^{2}$ correctly shows that the rectal branchiae of Libellula are outgrowths of the [hind] intestine, having at their extremity no epithelial cells, but only the intima (or cuticle) enclosing the tracheal filaments. The epithelium gradually grows thinner from the base towards the extremity of the branchial laminae, and at length disappears, being afterwards represented only by the cuticle. The tracheae divide dichotomously, finally becoming capillary airtubes, which this author also (being here inaccurate) supposes to reunite again into stronger stems. This part of his plate is so confused that one cannot make out whether the branches reunite again or not, and we presume that he did not try to follow them to their extremities.

In a specimen of these branchial laminae which we rolled under the cover-glass, we found that the multitude of tracheal ramifications ended

\footnotetext{
2 CHun, Carl. Ueber den bau, die entwickelung und physiologische bedeutung der rectaldrüsen bei den insekten. Inaugural-dissertation. . . Frankfurt a. M., ז875.
}

caecally; all were of about the same length, their extremities recurved within the containing sac, and their tips not at all swollen, but rounded off. Thus if they were stretched out they would form a brush like the hairs of a horse's tail. As they are elastic and the enclosing sac is distensible, we think it highly probable that with each water-inspiration the sacs enlarge and the tracheal spray (having air forced in by the forward compression of the large tracheac) spreads out so as to bring the full tide of air close to the tide of water. Léon Dufour seems to have had some process like this in view when he said that each lamella of the branchia of Potamophilus is "probably swollen during life by air transmitted by endosmosis." As we understand the case, the air is injected into the branchiae from the rest of the body by rhythmical contractions, and its gases then communicate endosmotically with those in the tidal water, so as to secure renovation.

The paper by $\mathrm{N}$. and $\mathrm{E}$. Joly on the larva of Prosopistoma ${ }^{3}$ confirms our observation. This larva was supposed by Latreille, Duméril and Milne-Edwards to be a branchiopod crustacean, and is so described in Milne-Edwards' Histoire des crustacés (v. 3, p. 558). But MM. Joly found out that it was the larva of a coleopterous insect, ${ }^{4}$ and they figure and describe its external

\footnotetext{
3 Joly, N. and E. Etudes sur le prétendu crustacé au sujet duquel Latreille a créé le genre prosopistoma, et qui n'est autre chose qu'un véritable insecte hexapode. (Ann. des sci. nat., Zool., IS72, s. 5, t. 16, no. 7, p. 1-16, pl. 13.)

4 It is in fact one of the ephemeridae..
} 
tracheal branchiae, showing that the branches of the tracheae end caecally. In this case the branches are so few that their terminations can be easily made out.

The importance of this anatomical item depends on its bearing on the functions of the whole tracheal system. The action of the tracheae is tidal rather than by peripheral capillary circulation. Here also the endings of the ramifications are found to harmonize with their internal terminations along the nervous and digestive tracts, and in other parts of the tissues which they supply. We never find a double system of tracheae with capillary rami- fications interposed for the transmission of air from one system to the other. It is not easy, in the living insect, to determine the ebb and flow directly; as the movements occur suddenly, have their speed multiplied by the degree of microscopic amplification; and hence we are able only to see the rhythmical peristaltic action, and are left to guess at its cause. We find, however, the muscular contractions and expansions of other parts of the body synchronizing with the pulsations in the gills, and thus explaining how the flux and reflux, rather than a mere circulation of the air, is the cause of its renewal.

Princeton, N. F., 12 Dec. 1883 .

\section{THE SCREW-WORM FLY, COMPSOMYIA MACELLARIA.}

BY SAMUEL WENDELL WILLISTON, NEW HAVEN, CONN.

IN connection with Professor Snow's article on this fly ${ }^{1}$ it seems worth while to give a brief synopsis of papers published in the past few years by the able dipterologist of South America, Dr. E. L. Arribálzaga, of Buenos Aires. From his studies he has ascertained no less than twenty-six different specific names that this fly had received! It is possible that some of these names would apply to distinct species were their types examined, but it is a thankless task to endeavor to make order out of the chaos in which Walker, Macquart, and Robineau-Desvoidy have involved the subject, and the result of Arribálzaga's thorough studies can with propriety be adopted.

Psyche, Mar.-Apr. I883, v. 4, p. 27-3o.
To these results, however, Mr. J. Bigot, of Paris, has recently taken exception, in a note ${ }^{2}$ on Professor Snow's paper. This author's penchant for making synonyms himself may perhaps have something to do with his wishing to preserve species founded on inadequate grounds. His argument that "il me semble fort hasardeux d'avancer qu'un seule et même espèce se retrouve, en permanence, depuis les confins de la Patagonie jusqu'au delà des provinces centrales de l'Amérique du Nord, vivant indifferemment sous les zones torrides, tempérées et même froides?" is of little value, when the

2 Bull. soc. entom. France, I2 Sept. I883, no. I7, p. I54-I 55 . 

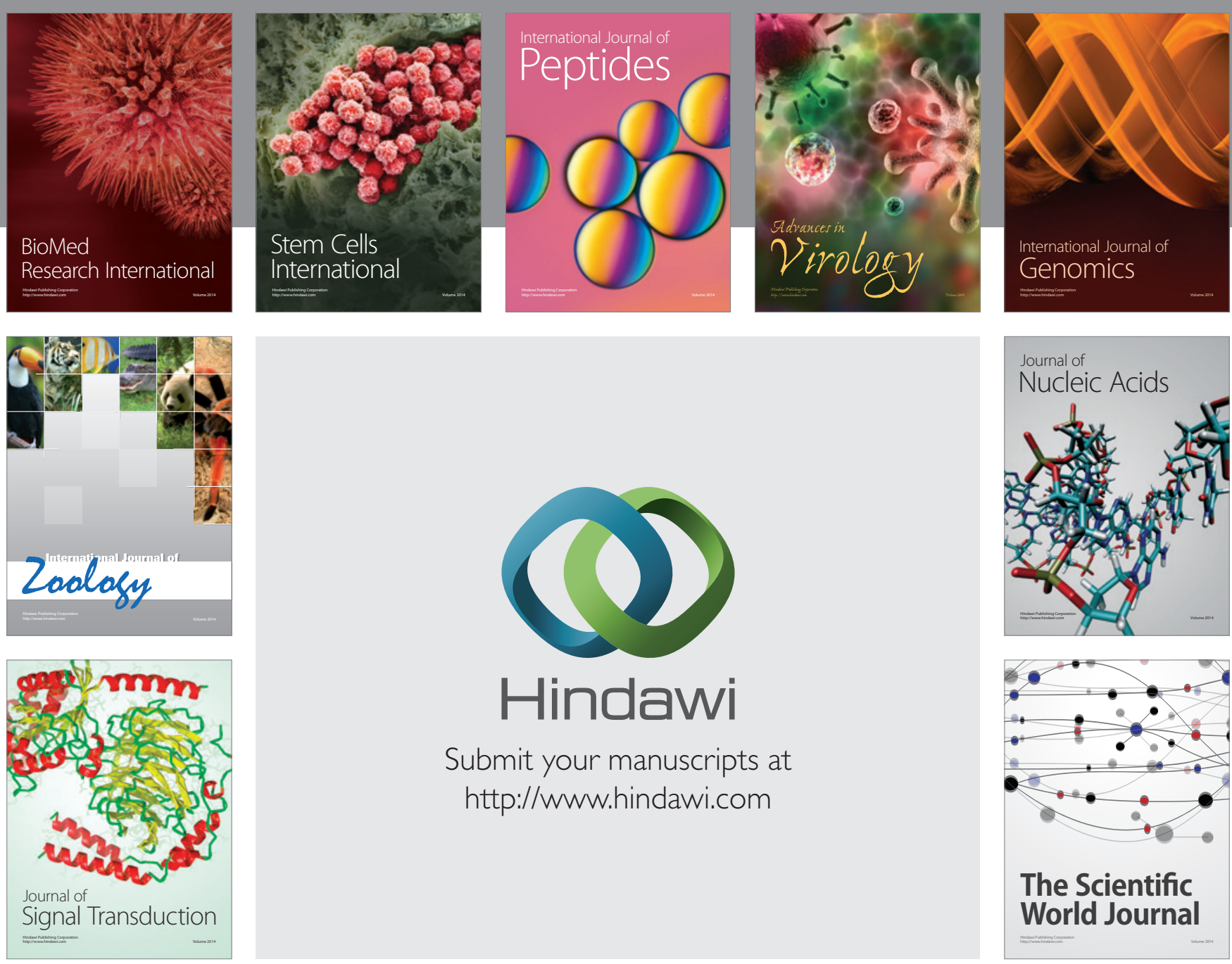

Submit your manuscripts at

http://www.hindawi.com
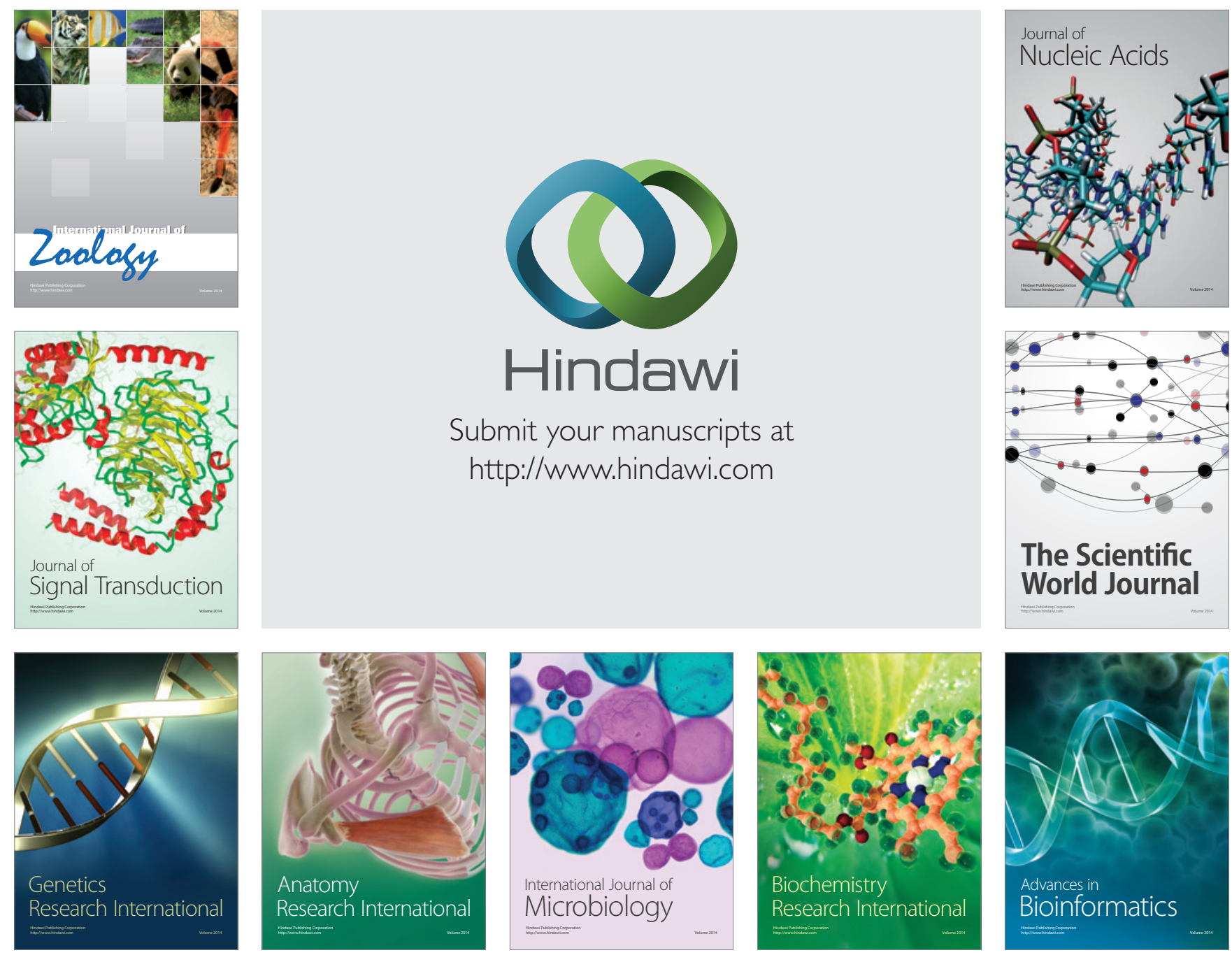

The Scientific World Journal
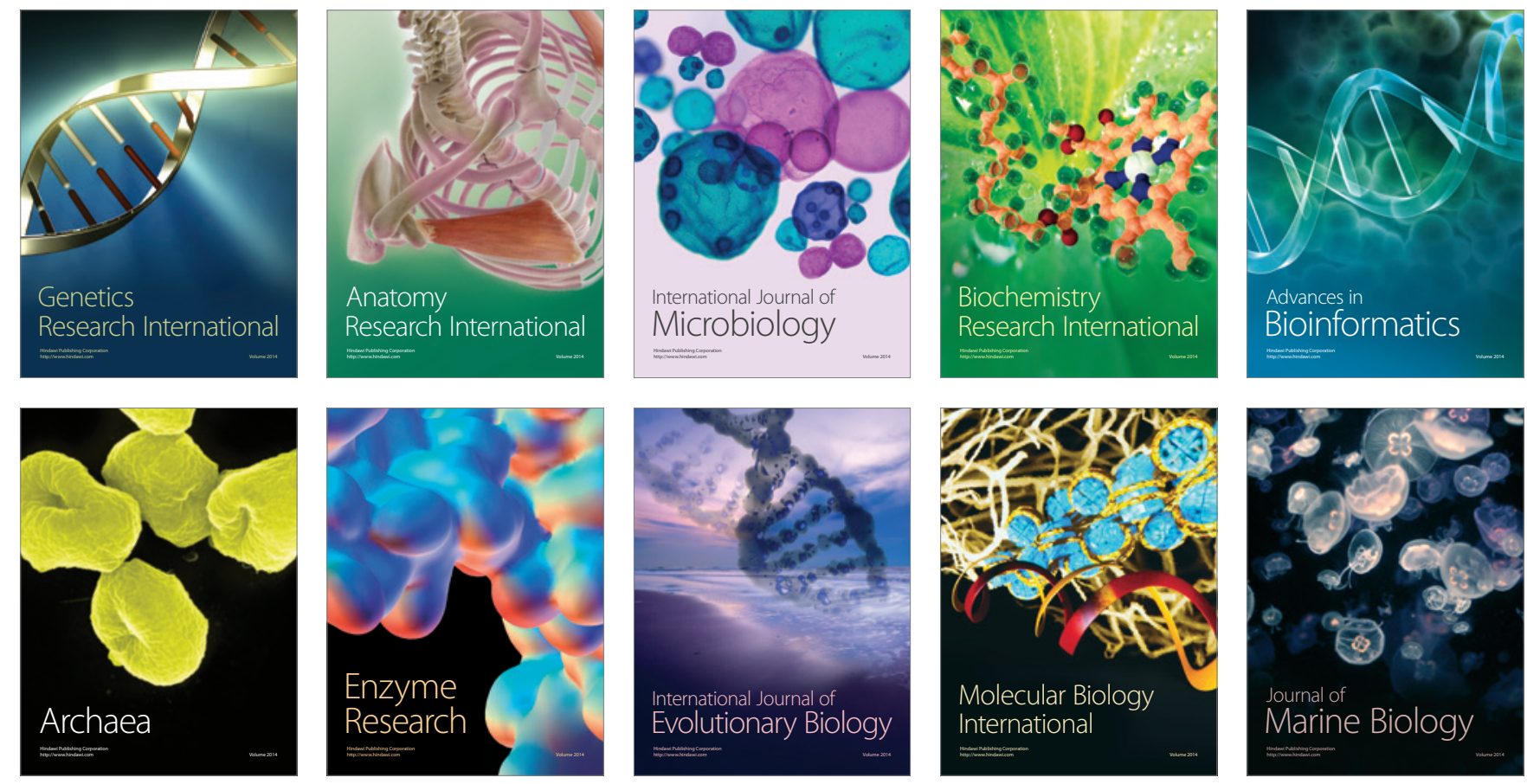